\title{
Food Terrorism in Nigeria: Fears, Possibilities and Action
}

\author{
Kenneth Chukwuemeka Nwoko \\ Lecturer, Department of History and International Relations \\ Redeemers' University, Ogun State, Nigeria \\ Tel: 23-480-3612-7492Ｅ-mail: nwokokenneth@gmail.com
}

\begin{abstract}
The September 11, 2001 attacks on the United States, the subsequent anthrax follow-up and the US embassy attack in Kenya not only demonstrated the extent and possibilities of terrorist attacks on both the weak and strong and even the most sophisticated security conscious of nations, but also the extent, methods and forms which the perpetrators can employ to make their statement or achieve their objectives. These and other events around the world reflect the emerging typologies of the phenomenon in contemporary times

The US Food and Drug Administration (FDA) at a time raised fears of a high likelihood, in the future, of food terrorism or an incident of unintentional food contamination that would result in serious food borne illness that would affect a significant number of people. The question then is, since no country is isolated in international politics and bearing in mind the symbolic nature of most terrorist acts, what are the possibilities of such attacks on Nigeria's food supply and what are the emergency response capabilities of the country in such occurrences.

The geopolitics of Nigeria and her status as the most populous black nation in the world as well as the inherent religious intolerance in her domestic politics in particular the Maitasina riot, Bokoharam disturbances and Talakuta riot are all pointers to the precarious position of the country on the terrorist drawing board.

This work analyzes the possibilities of food terrorism in Nigeria. It examines the factors that heighten the susceptibility of the country to such attacks and evaluates the country's emergency response capabilities in the face of such reality. The paper argues that just as other countries have learnt from the US experience, Nigeria should also perfect her strategies to counter or manage such eventualities.
\end{abstract}

Keywords: Anthrax, Contamination, Food, Terrorism, Attacks, Geopolitics

\section{Introduction}

The phenomenon of terrorism is historical, however, the end of the Cold War brought with it new forms and dimensions of the phenomenon hitherto unimaginable. The breakthroughs in science and technology enhanced the sophistication and finesse with which the phenomenon is re-invented and heightened, especially as dialogue by other forms. Hans Morgenthau highlighted some of the elements of state power, which included; geography, population, military might, economic strength and also food resource. (Morgenthau, 1960) In contemporary times some of these elements are not as vital as they used to be due mainly to innovations in science and technology. In the contemporary international politics, the issue of food resources and strategic resource management are beginning to play vital roles in world politics and diplomacy as Osuntokun (2009:1) pointed out in his statement at the $64^{\text {th }}$ session of the United Nations' General Assembly. This is not to suggest that food was not used as a political tool in time past. (Messer, et al, 1998:3) A nation that is sufficient in vital resources such as food production would be able to play international politics from a position of strength and to its advantage. Africa for example produces less than 10 percent of the total world food production yet over 10 percent of her population is engaged in agriculture. The point here is that despite her natural and human resources, Africa has continued to remain a dependent continent in every aspect including food production and supply, hence her susceptibility to international food crisis.

Most African countries, south of the Sahara, share the largest ratio in food aid and support from food donour agencies and world bodies. Oftentimes, this is as a result of their inability to feed themselves caused by natural disasters such as draught and famine. Ethiopia's situation in the 1980s and that of Chad in the 1990s are still cases in point, while others are caused mainly by civil wars and the consequent refugee situations, such as the case of Somalia, Liberia and Sierra Leone. Also the crude method of agricultural production still extant in most African countries makes it impossible to achieve any large- scale production at least to meet internal needs. This underscores the significance of food as an element of strength and power in world politics as well as a weapon of asymmetric warfare in contemporary times.

\section{Food and Terrorism Elsewhere}

Elsewhere, particularly in Europe and North America where food production is optimal, thus creating self sustenance, and even surplus for exports, a particular fear has arisen; the fear of food terrorism. This was a concept 
seldom thought about until the September 11, 2001 attacks on the US by the Al-Qaeda terrorist group which aroused the fears of bio-terrorist experts to the possibilities of a future target on the food supply system of the United States. According to the U.S. Department of Health and Human Services (DHHS) bio-terrorism is "the use or threatened use of biological agents or toxins against civilians, with the objective of causing fear, illness, or death."(Bray and Konsynski, 2006:560) As in other typologies of terrorism, the role of fear is central to the event; if the sole intention is to cause death, there are much easier ways to cause a mass casualty situation. This is where food becomes an option. Food terrorism therefore can be defined as the use or threatened use of contaminated or poisoned food against civilians, with the objective of causing fear, illness, or death and most significantly for political reasons. Food terrorism, while rare, is not new to the United States. The case of the Indian Guru Bhagwan Shree Rajneesh almost a decade ago who infected 10 salad bars in the Dalles, Oregon, with the potentially deadly salmonella pathogen was only but one of such occurrences in the US. In that incident, it was reported that about 750 residents were sickened from the exposure. (Weese, 2002) Indeed, the confirmation of such fears on the heels of the Anthrax attack on the country despite over $\$ 100$ million spent by the Food and Drug Administration in 2002 alone, on measures to safeguard the US food supply against bio-terrorist attacks, (Welcome Newsline, 2002) only demonstrated the fitness of this method as a terrorist weapon for political objectives. Several cases of food sabotage have occurred in the United States. Even before the September 2001 attacks, in 1984, a cult group contaminated salad bars with salmonella to disrupt a local election.( Fabi, 2006) The incident resulted in 751 illnesses, including 45 hospitalizations. There were other reported cases of food poisoning and contamination.

In a special report in 2003, the World Health Organization (WHO) warned of a possible contamination of food supplies by terrorist groups employing chemical or biological agents and advised countries to strengthen their surveillances to avoid death or the contracting of serious illnesses like cancer.( Kirby, 2003) Generally, food supply is especially vulnerable to an attack because of the broad range of biological and chemical agents that can be used as well as their easy accessibility without suspicion. However, this is predicated on the terrorist's belief that killing or harming the largest number of people could prove the simplest and most powerful way to make a political statement. (Weese, 2002)

\section{Nigeria's food production and Distribution}

Within the African sub-Saharan region, Nigeria stands out as the most populous nation, making her more susceptible to crisis arising from breaks in international food supply system and international food crisis and insecurity, caused either by natural factor such as that witnessed in 2008, or man-made factor such as the periodic bans on certain food items either prone to infections by contagious diseases or as a management strategy to curb the spread of such diseases or even diplomatic retaliatory measures. Furthermore, experience has shown that the influx of refugees into the country from neighbouring countries in the West African sub-region often times led to food shortages. All these heighten the politics of food production, importation and distribution in Nigeria, and a convenient means of getting at the largest number of people, rich or poor, (food production includes water production and distribution).

Within the domestic food distribution chain, the inefficient food defence and safety measures allowed for the proliferation of unmonitored food outlets such as road side eateries, snack shops, bar and open air canteens, exposing them as easy medium for food contamination or poisoning by terrorists. Similarly, the circulation of fake and adulterated pharmaceutical products by some syndicates has not only jeopardized the life of patients, but has also demonstrated the intractability of the phenomenon, the vulnerability of Nigerians and the enormous challenges facing the National Food and Drug Administration and Control, (NAFDAC)( Owolabi,2008) It also suggests that "no matter the funnel put on preventing impurities from the system, at the end of the day, the imperfections of our postcolony would prevail"'( National Life, 2008:56) The case of the deaths of over forty children in Nigeria after the administration of a teething mixture called 'My Pikin' did not suggest any terrorist connection but the devastation and the possibility of similar incident with terrorist motives. Similarly, the report of the poisonous Sallah meal that killed dozens of people in a Lagos suburb in 2009 ranks the least of such reports supporting the possibilities of food terrorism. At the international entry points, both land and sea, though there are some security measures in place to ensure that imported food material conformed to international standards, however, most of these measures oftentimes are circumvented by the unscrupulous business cartels in connivance with the very officials in charge of those stations, thus, allowing that possibility of terrorist infiltration of the food supply and industry of the country. Consequently, deliberate contamination of the nation's food supply is a real possibility and the economic and psychological implications of an attack on the food supply are frightening. Some foods are more susceptible to deliberate contamination than others, but there is no practical way one can eliminate the possibility of being affected. Food terrorism utilizes a vector that affects everyone.

Existing Terrorism Management Strategies and Organs in Nigeria 
Nigeria's attempt at handling the issue of terrorism generally is only at a snail speed. Almost a decade after terrorism became a global quagmire; the country's concern and awareness about the phenomenon are still budding. Currently, the Anti-terrorism, Economic and Financial Crimes Act set out to criminalize terrorism has still not been passed by the country's legislature. Until such laws are enacted, Nigeria does not have the judicial competence to deal with crimes committed by Nigerians outside the country, or foreigners within the country especially as relating to terrorist acts. (There is no law criminalizing terrorism in Nigeria)

Generally, the Nigerian Police Force, State Security Services (SSS), Immigration Department, and the Central Bank of Nigeria work in concert to share intelligence and prevent crimes. However, it was not until the September attacks on the United States in 2001 that measures and strategies put in place for effective monitoring were reviewed and enhanced, including tighter watch on financial transactions, supervision of border patrol, and heightened monitoring of suspected terrorist groups. Furthermore, there is also the Joint Intelligence Board, which exists as a consortium of Nigerian government organizations which focuses on curbing and preventing terrorism and terrorist activities in the country. However all these are general focused agencies on crime and terrorism. Indeed, while agencies such as the National Bio-safety Committee (NBC), National Agency for Food and Drug Administration and Control (NAFDAC), Standard Organisation of Nigeria (SON) and other such agencies may be indirectly checking unsafe and unhealthy practices in the food, drug, beverages and drink industries, the truth remains that there are no direct and clear cut focus or mandate on prevention and management of food terrorism, neither are there terms of reference on food defence nor food safety.

In a country with a record of ineptitude to the issue of monitoring and enforcement of international standards on the production or importation of food, drugs, drinks and beverages by agencies of government, the accessibility of such production or importation points by persons bent on infecting the food chain is unhindered. The unchecked proliferation of sachet water and unorthodox drug manufacturing and peddling in the country demonstrates the unfettered manner with which such centers could spring up without detection. Though attempts are made by these regulatory bodies mentioned above, the fact still remains that the needed resources; equipment, technological know-how and competent personnel to handle the job effectively are inadequate, thus, still allowing such little possibilities which could be taken advantage of by any terrorist group to achieve its objective. Apart from the inadequate resources to monitor security and safe practices, the security attitude and consciousness of the average Nigerian is still low. The public attitude therefore, about food safety and food defense is abysmally poor. This is not unconnected with the lack of awareness, general poverty situation in the country and the lack of trust and confidence on government agencies and parastatals which are largely seen as inefficient, corrupt and oftentimes conniving with unscrupulous foreign and local businessmen.( Daily Sun,2008:6) The reported terror alert in the Daily Sun of Thursday July 31, 2008,( Daily Sun,2008:6) re-echoes the lack of trust not only on government establishments and their officials, but also the possibility of their connivance with foreign firm to undermine the country's internal security

\section{Nigeria as Terrorists' Target}

Policy makers and the food industry the world over are beginning to recognize the importance of guarding food supply from terrorism. Preparing for, protecting against, and planning responses to attempts to deliberately contaminate food with toxins and poisons with high mortality rates have become an international and a food industry priority. However, it should be noted here that any terrorist attack by any unscrupulous group may not be directly targeted at the Nigerian people, but against the interest of some super powers like the US, Great Britain or other countries perceived to be in the camp of the 'enemy' by the terrorist group concerned. Indeed the terrorist attack on the American embassy in Kenya was not targeted at the Kenyan nation but the symbol of the US presence in that country. Nevertheless, the consequent psychological and economical impact was borne largely by the Kenyans. International terrorist organizations, including Al-Qaeda, Lebanese Hezbollah, and Egyptian terrorist groups, have continued to operate in Africa since the 2001 attacks largely to undermine US interests. Invariably, any means of, and opportunity at making a symbolic statement would definitely be employed by these groups.

Apart from targeting the United States' interest in Africa, there is the likelihood of attacks on those countries that are sympathetic to the US cause or serve strategic interest of the US. Indeed, Nigeria is the most important trade partner of the US in the West African sub-region and one of the most important in Africa. With oil and natural gas constituting about $37 \%$ of Nigeria's GDP as at 2006, the country's export earnings of over $\$ 59$ billion has petroleum in the lead with about $95 \%$ of the total earnings. (Bureau of African Affairs, July 2008) The United States constitutes, the biggest trade partner of Nigeria with about $52 \%$ share of the country's total petroleum export,( Bureau of African Affairs, July 2008) as the information below reveals;

Nigeria is the United States' largest trading partner in sub-Saharan Africa, largely due to the high level of petroleum 
imports from Nigeria, which supply $11 \%$ of U.S. oil imports--nearly $46 \%$ of Nigeria's daily oil production. Nigeria is the fifth-largest exporter of oil to the United States. Total two-way trade was valued at $\$ 35$ billion in 2007, a 17\% increase over 2006. Led by machinery, wheat, and motor vehicles, U.S. goods exports to Nigeria in 2007 were worth $\$ 2.2$ billion, up $25 \%$ from 2006. U.S. imports from Nigeria were $\$ 32.7$ billion in 2007, up 17\% from 2006. U.S. imports from Nigeria consisted predominantly of oil. However, rubber products, cocoa, gum arabic, cashews, coffee, and ginger constituted over $\$ 70$ million of U.S. imports from Nigeria in 2007, up 45\% from 2006. The U.S. goods trade deficit with Nigeria was $\$ 32.8$ billion in 2007, a slight increase from 2006 data and representing the seventh-largest deficit for the United States with any country worldwide. Nigeria is currently the 50th-largest export market for U.S. goods and the 14th-largest exporter of goods to the United States. (Bureau of African Affairs, July 2008)

Similarly, on global investment flow into Nigeria, the United States remains the largest foreign investor in Nigeria. In 2004 alone, the stock of US foreign direct investment (FDI) in Nigeria was \$2 billion although it went down to $\$ 874$ million in 2005. US FDI in Nigeria is concentrated largely in the mining and wholesale trade sectors. (Bureau of African Affairs, July 2008) The United States and Nigeria met in April 2008, under the existing Trade and Investment Framework Agreement (TIFA). This meeting was to advance the ongoing work program and to discuss improvements in Nigerian trade policies and market access. Among the issues raised were cooperation in the World Trade Organization,(WTO) market access, export diversification, intellectual property protection and enforcement, commercial issues, trade capacity building and technical assistance, infrastructure, and investment issues.( Bureau of African Affairs, July 2008) These collaborations no doubt ranked Nigeria among the first class of countries that the United States considers as being of great importance to her relevance in international politics and an ally in the war against global terrorism as the information below reveals;

The government [of Nigeria] has lent strong diplomatic support to U.S. Government counter-terrorism efforts in the aftermath of the September 11, 2001 terrorist attacks. The Government of Nigeria, in its official statements, has both condemned the terrorist attacks and supported military action against the Taliban and Al Qaeda. Nigeria also has played a leading role in forging an anti-terrorism consensus among states in Sub-Saharan Africa. (Bureau of African Affairs, July 2008)

This is not only for Nigeria's geo-politics but also her position in Africa as the most populous country and a regional power. Beyond international terrorism, the internal dynamics of Nigeria's politics has also left her vulnerable to terrorist attacks. The brewing religious sectarianism can only result in extreme and fanatical methods of punishing the target population or section of the country considered 'ungodly' by religious extremists. It is in this regards that recent developments in the northern part of the country especially would be discussed.

In the early 1980s the rise of Islamic sects in the northern part of the country which led to the Maitasina riot was the earliest form of religious fanaticism that ever developed in the country. However, the influx of Islamic fundamentalists especially at the beginning of the US fight against the Al-Qaeda and other fundamentalists from Nigeria's contiguous states in the north such as Chad and Niger heightened the fears of possible religious violence in the country. This fear has been subsequently confirmed by the avalanche of religious conflicts that occurred especially in the northern part of the country. In particular, the recent religious fundamentalism of the Bokoharam, an Islamic sect opposed to western education and the Talakuta riot are all pointers to the precarious position of the country on the terrorist drawing board.

The appearance of Islamic leftist, the 'Taliban', in the North in 2005, was an indication of the infiltration of the country by Islamic fundamentalists. The fear is that with countries of North Africa fully infiltrated by Al-Qaeda Netwar (Nwoko, 2005:253) pattern of small cell groups, the possible development and importation of terror based on religion into Nigeria remains certain. The porosity of the Nigerian borders in the North, and the daily influx of the Al-Majeris who have been constantly used to ferment trouble by religious fundamentalists pose a serious treat to the country's security. The point here is that these groups can employ all means to get at their target including using the Al-Majeris to poison the eateries, food outlets and production points. This threat is further made real by the radicalisation of Islam in the North with the introduction of Shariah in several northern states of Nigerian. Similarly, it appears that aggressive missionary work in the North by Saudi Wahabis has played a decisive role in escalating the conflict between Christians and Muslims; (Mair, 2003) a conflict that has been recurrent at every slightest provocation. Such include the conflict following the aborted Miss World competition in 2002 and the riot arising from the caricature made in 2006 in a Danish Newspaper publication of Prophet Mohammed, (SAW) far away from Nigeria.

Further down in the volatile Niger/Delta region, the menace posed by the militant groups has become worrisome. But more worrisome is the unpredictability of the means employable by this aggrieved group to drive home their 
agitation. The targeting of expatriates oil workers for kidnap, explosion of oil pipes and attacks on oil installation have been the terrorists weapons of making their statements. However, the recent turnaround towards killing and kidnapping of the local population especially the rich, has open a new vista on options available to the militants, wouldn't the contamination of public food in the region be attractive to them?

Further, a closely related threat is that posed by imported food and food materials. Recently, there have been cases of food poisoning and contamination emanating from imported food around the world, especially from countries that are grappling with food safety problems. In late January, 2008, the case of the frozen dumplings which were contaminated with a highly toxic organophosphate pesticide, methamidophos, was reported in Japan.(BBC News, 2008) The Chinese dumplings which were laced with pesticide made at least 10 Japanese people ill. Japan's health minister believed that they were poisoned on purpose. (BBC News, 2008) Similarly the case of the contaminated Chinese wheat gluten that poisoned cats and dogs in the United States and led to a massive pet food recall (see 'Imported food rarely inspected') was just another out of the many cases of food poisoning from source and an unsavory taste of what is to come. Recently the United States FDA detained nearly 850 shipments of grains, fish, vegetables, nuts, spice, oils and assorted imported foods for issues ranging from filth to unsafe food colouring to contamination with pesticides to salmonella.(see 'Imported food rarely inspected') Yet, despite the huge efforts put into the fight as well as resources at their disposal, Mike Doyle, director of the University of Georgia's Center for Food Safety, still considers the FDA as not having "enough resources or control over this situation presently."(see 'Imported food rarely inspected') Consequently, there are fears that the US is still vulnerable to harm from abroad, where rules and regulations governing food production are often more lax than they are in the US. This suggests the huge cost of safeguarding the domestic population from threats of food poisoning from abroad. The question then is, does Nigeria have the wherewithal to ensure that the food it imports is safe?

The advancement in science and technology no doubt has improved global food production in the face of the ever increasing world population. Some of the discoveries have also had their negative effects on the human population. The breakthroughs in the area of biotechnology especially in the use of molecular biology techniques to create crop plants known as genetically modified (GM) crops for human and animal consumption in recent times have come under very serious controversies. Environmentalists and Public health groups have raised alarm on the dangers associated with the use of genetically modified crops on the environment, human and animal health. (Whitman, 2008:1) Though these crops are modified in the laboratory to enhance desired traits such as increased resistance to herbicides or improved nutritional content, experts believe that their negative effects on the environment and on humans far more outweigh the positive outcomes. Recent studies about the effects of genetically-modified corn pollen on monarch butterfly caterpillar have raised further concerns on the health implications of genetic engineering.(Nature,199:214) These concerns were not unconnected with the potential human health impact: allergens, transfer of antibiotic resistance markers, and some other unknown effects.(Human Genome Information Project, 2007) Similarly, the potential environmental impact include; unintended transfer of trans-genes through cross-pollination, and sundry unknown effects on other organisms such as soil microbes, and loss of flora and fauna biodiversity(Human Genome Information Project, 2007)

In the face of the danger posed by this new technology, many countries are cautious about the importation and use of GM foods. In the peak of the Zimbabwean food shortage, attempts were made by food donour agencies to supply the country with such food materials which of course met total rejection by the Zimbabwean authorities. In like manner, both the Vatican (Biotechnology, 2000:7) and the Prince of Wales (1998) have expressed similar concerns about GM foods. The anxiety here is that these GM foods may find their way into Nigeria covertly or overtly without the authorities exercising adequate regulatory oversight in the rush to ensure food security in the face of the international food crisis.

\section{Nigeria's Emergency Response capabilities}

The experience of Nigeria in emergency management overtime has been abysmally poor. The incidences of fire out breaks, collapse buildings and deadly diseases like bird flu have always broken the country's elasticity to manage such emergences. Oftentimes the relevant agencies such as National Emergency Management Agency (NEMA), the Nigerian Fire Services, Nigerian Civil Defence Corps and a host of other agencies have been found wanting in the discharge of their statutory responsibilities. In most cases these agencies have attributed their non-performance to the lack of necessary resources such as equipment, skill personnel and the right motivation to perform optimally.

Apart from these obvious inadequacies, the lack of well articulated and appropriate government policies to ensure national emergency preparedness, capacity building and training in the field of disaster and emergency management seem to be lacking. Hence, it is advisable that Nigeria should collaborate with international disaster and emergency experts such as the International Committee of the Red Cross (ICRC) and its other affiliate bodies like the 
International Federation of the Red Cross and Red Crescent societies to fashion out a practicable blueprint for disaster management in the country.

\section{Conclusion}

The threat of food terrorism in Nigeria no doubt is more real than imagined. The development of a genuine Nigerian variant of counter-terrorism strategies cannot be over emphasis. The country, of necessity however, needs to align with other countries especially the US, and international bodies to form a uniform response to the threat posed by food terrorists. Similarly, a functional anti-terrorist legislation is of great importance to the country especially to define the boundaries of what constitutes terrorism and its dimensions. Sequel to it is a functional criminal justice system that would ensure transparency. However, both anti-terrorist legislations and functional justice system would amount to little more than a symbolic value when lack of political and economic perspectives, social deprivation and injustice, political repression are virtually omnipresent in Nigeria. Indeed, marginalisation, insincerity of Nigeria's political class and leaders thrive as normal national dictum. Similarly, just as in any other part of Africa, (Cilliers, 2003:102) Nigeria should be made safer for its own people. This will also possibly make it safer for the Americans and a better way of aligning with them in the fight against international terrorism, a phenomenon which was exacerbated by the United States' policies and actions around the world.

On a regional level, African countries under the aegis of the African Union should consolidate efforts already made in the fight against terrorism. In this regard, the established Centre for the Study and Research on Terrorism (ACSRT), in Algiers, Algeria,( Konaré, 2008) should be effectively utilized to boost the capacity of the African countries to prevent and combat terrorism within their individual states as well as strengthen their collective efforts and translate their commitments into concrete actions.

\section{References}

Background Note: Nigeria, Bureau of Public Affairs: Electronic Information and Publications Office Bureau of African Affairs, July 2008. Available: http://www.state.gov/r/pa/ei/bgn/2836.htm\#history (September 20, 2008).

Bray, D.A. \& Konsynski, B.R. (2006). 'Fighting Fear of a Bioterrorism Event with Information Technology: Real-World Examples and Opportunities,' in Mehrotra S., Zeng, D.D,, Thuraisingham, B. Chen, H., \&Wang, F. (2006) (Eds.): Intelligence and Security Informatics, LNC Volume 3975, DOI: 10.1007/11760146, Springer-Verlag Berlin Heidelberg pp.560-565.

Cilliers, J. (2003). 'Terrorism and Africa' African Security Review 12 No 4.

Dumplings poisoned 'on purpose', BBC News, Tuesday, 5 February 2008, 12:34 GMT.

Fabi, R. (2003). 'FDA warns of 'food terrorism', Reuters, Globe Newspaper 2006 [Online] Available:http://www.boston.com/news/nation/articles/2003/10/11/fda_warns_of_food_terrorism/.

'Food Terrorism, Possible, But Not Likely, Expert Says.' Welcome News line Auburn, May 16, 2002 [Online] Available: http://www.aces.edu/dept/extcomm/newspaper/may16e02.htm (June 4, 2008).

For more see, 'Imported food rarely inspected.' [Online] Available: http://www.usatoday.com/news/nation/2007-04-16-imported-food_N.htm?csp=34 (June 9, 2008).

'Genetically Modified Foods and Organisms -HGP ethical, legal and social issues- Human Genome Information Project, [Online] Available: http://www.ornl.gov/sci/techresources/Human_Genome/elsi/elsi.shtml (August 20, 2008).

GMO Roundup Nature Biotechnology, Vol 18, Jan 2000.

Mair, S. (2003). 'Terrorism and Africa' African Security Review Vol. 12 No 1 (Online) Available: http://www.iss.co.za/pubs/asr/12no1/CMair.html (June 4, 2008).

Messer, E, Cohen M. J. \& D’Costa, J. (1998). 'Food from Peace Breaking the Links between Conflict and Hunger' Food, Agriculture, and the Environment Discussion Paper 24, International Food Policy Research Institute, Washington DC.

Morgenthau, H. (1960). Politics among Nations the Struggle for Power ad Peace New York: Alfred A. Knopf.

National Life Vol. 1 No 20 Saturday November 29- Friday December 5, 2008.

Ojo, J. (2008). 'Terror Alert: Reps Accuse Nigerdock of Aiding Terrorists' in Daily Sun, Thursday, July 31.

Osuntokun A. (2009).was Nigerian first Ambassador and plenipotentiary to united Germany and currently a member, Presidential Advisory Council on Foreign Affairs. He issued this statement at the 64th session of the United Nations' General Assembly. Agenda Item: Eradication of Poverties and other Development Issues (Second 
Committee) New York, October 22.

Owolabi, T. deputy director, inspectorate establishment, NAFDAC, speaking on 'update on fake teething mixture' an African Independent Television programme Kakaki the African Voice, monitored in Lagos, on the 28th November, 2008. Professor Dora Akunyelu, Director General of NAFDAC appeared on the same programme the previous day on the same fears and concerns.

Konaré, A.O (2008). 'Preventing and Combating Terrorism in Africa' [Online] Available at http://www.africa-union.org/Terrorism/terrorism2.htm (August 20, 2008).

HRH the Prince Charles, (1998). 'Questions about Genetically Modified Organisms' [Online] Available: http://www.princeofwales.gov.uk/speeches/agriculture_01061999.html).

Nwoko K., C. (2005). 'The Nature and Dimension of Terrorism in the Post Cold War Palestine and Iraq' in Nigerian Journal of Policy and Development, Vol. 4, pp.246-269.

Transgenic pollen harms monarch larvae (Nature, Vol 399, No 6733, p 214, May 20, 1999). Also Assessing the impact of Cry1 Ab-expressing corn pollen on monarch butterfly larvae in field studies (Proceedings of the National Academy of Sciences, Vol. 98, No 21, p11931-11936, Oct 2001).

Weese, J. (2002). 'Extension Food Scientist', 334-844-3269, Welcome Newsline Auburn, May 16. Available:http:/www.aces.edu/dept/extcomm/newspaper/may16e02.htm (June 4, 2008).

Whiteman, D.B. (2008). 'Genetically Modified Foods: Harmful or Helpful?' in Discovery Guides, p.1 [Online] Available: http://www.csa.com/discoveryguides/gmfood/review.pdf (August 20, 2008).

Emma Jane Kirby, (2003). 'WHO issues alert on food terrorism' BBC NEWS world edition, [Online] Available: http://www.cfsan.fda.gov/ dms/rabtact.html (June 4, 2008). 